\title{
AULACOSEIRA SKVORTZOWII SP. NOV. (BACILLARIOPHYTA), A POORLY UNDERSTOOD DIATOM FROM LAKE BAIKAL, RUSSIA ${ }^{1}$
}

\author{
Mark B. Edlund, ${ }^{2}$ Eugene F. Stoermer \\ Center for Great Lakes \& Aquatic Sciences, University of Michigan, 2200 Bonisteel Boulevard, \\ Ann Arbor, Michigan 48109-2099 \\ and \\ Christine M. Taylor \\ Department of Marine Science, University of South Carolina, Columbia, South Carolina 29208
}

\begin{abstract}
Aulacoseira skvortzowii $s p$. nov. is a diatom taxon present in modern plankton assemblages and sedimentary deposits from Lake Baikal, Russia. It has been previously reported as A. islandica ( $O$. Müll.) Simonsen, A. islandica $s s p$. helvetica (O. Müll.) Simonsen, a sporangial frustule of A. baicalensis (K. Meyer) Simonsen, and Aulacoseira "spore." However, its microstructure, ecology, and ability to form true resting spores provide ample criteria to describe this diatom as Aulacoseira skvortzowii sp. nov.
\end{abstract}

Key index words: Aulacoseira skvortzowii sp. nov,; Bacillariophyceae; Lake Baikal; life history; Melosira; new species; resting spores; taxonomy; ultrastructure

Lake Baikal is located in south-central Siberia along the Baikal Rift Zone $\left(51^{\circ} 43^{\prime} \mathrm{N}, 103^{\circ} 44^{\prime} \mathrm{E}\right.$, to $\left.55^{\circ} 46^{\prime} \mathrm{N}, 109^{\circ} 37^{\prime} \mathrm{E}\right)$. It is the largest, deepest, and probably oldest existing lake on earth. The lake is estimated to be nearly 25 million years old and is underlain by over $7 \mathrm{~km}$ of sedimentary accumulation. Because of this long history and relative geographical isolation, the Baikal ecosystem has developed high degrees of endemism at all levels of the food web (Kozhov 1963). While the world's only freshwater seals, pelagic sculpins, and $8-\mathrm{cm}$-long gammarids attract much of the popular and scientific attention, the diatom flora of Lake Baikal also exhibits extreme diversity and extensive endemism. The benthic and periphytic diatom flora are especially diverse with over 500 taxa reported; as many as one-third of these are endemic (Meyer 1930, Kozhov 1963). In contrast, the planktonic flora is relatively nondiverse. Approximately 52 species of planktonic diatoms have been reported; however, the plankton is characterized by significant populations of only eight taxa (Popovskaya 1993).

Four of the most important planktonic diatoms in Baikal are endemic. Three species of Cyclotella, $C$. baicalensis Skv. \& Meyer, C. ornata (Skv.) Flower, and C. minuta (Skv.) Antipova typify the midsummer to

\footnotetext{
${ }^{1}$ Received 22 May 95. Accepted 19 October 1995.

${ }^{2}$ Author for reprint requests.
}

late fall pelagic plankton community. Cyclotella minuta dominates the modern assemblage whereas $C$. ornata and $C$. baicalensis have become much less abundant in recent years (Popovskaya 1991, Flower 1993). The vernal phytoplankton is usually dominated by Aulacoseira baicalensis (K. Meyer) Simonsen. This filamentous centric taxon begins its development beneath clear ice as early as February and continues to dominate the plankton through May or June. Population numbers vary greatly from year to year, producing what are known as "Aulacoseira" years every $3-4$ years, when $A$. baicalensis dominates the pelagic plankton. The endemic Cyclotella typically have greater development during "Aulacoseirapoor" years. The controlling factors governing this cycling of populations are poorly understood but may be related to reproductive cycles.

A second Aulacoseira species, which has a seasonal distribution similar to that of $A$. baicalensis, is the subject of this study. Previous workers have referred to Baikal's populations of this taxon as Melosira baicalensis (K. Meyer) Wislouch "sporangial frustule" (Skvortzow 1937), Aulacoseira (Melosira) islandica ssp. helvetica (O. Müll.) Simonsen (Kozhov 1963, Kozhova et al. 1982), A. islandica (O. Müll.) Simonsen (Genkal and Popovskaya 1990, 1991a, b, Bradbury et al. 1994), or just Aulacoseira "spore" (Edlund et al. 1995, Stoermer et al. 1995). It is commonly encountered in both the nearshore and pelagic plankton of Baikal, has a temperature growth optimum of $4^{\circ}-6^{\circ} \mathrm{C}$, and forms morphologically distinct resting spores in the absence of light (Bondarenko et al. 1993, D. H. Jewson, pers. commun.).

The production of true resting spores, or hypnospores, is especially common in temperate neritic marine diatoms but is a relatively rare occurrence among freshwater forms, mostly limited to Urosolenia, Acanthoceras, Aulacoseira, and the inland Chaetoceros (Ehrlich 1973, Hargraves and French 1983, Rushforth and Johansen 1986, Edlund and Stoermer 1993). Resting spores are usually easily distinguished from vegetative cells by their thickened, modified, siliceous frustule, which presumably provides added protection against darkness, desiccation, and grazing (Hargraves and French 1983). Most freshwater planktonic diatoms form physiological 
resting cells instead of resting spores as a perennation strategy. Valves of resting cells are morphologically indistinguishable from vegetative cells; however, resting cells are cytologically distinguishable from vegetative cells by their dark, condensed cytoplasmic mass that is composed of chloroplasts, mitochondria, and storage products surrounding the nucleus (Sicko-Goad et al. 1989). Resting cells are capable of surviving anoxic conditions and lengthy time periods incorporated in sedimentary deposits (Sicko-Goad et al. 1989), whereas resting spores remain viable for only a couple years (Hargraves and French 1983). Most planktonic diatoms have been reported to produce either spores or resting cells as a perennation strategy, but some may use both strategies (Kuwata et al. 1993).

Because of the confusing nomenclatural history of this Aulacoseira taxon and relatively rare occurrence of resting spores in freshwater diatoms, we investigated its ultrastructure and taxonomy and reviewed its relation to closely allied species. Our results identify significant differences between it and previously described species, justifying its description as a new taxon, A. skiortzou'ii.

\section{MATERIALS AND METHODS}

Phytoplankton was collected from Lake Baikal on 28 May 1994 with a $63-\mu \mathrm{m}$ mesh plankton net towed vertically from $50 \mathrm{~m}$ to the surface at Station Listvinichnoe-Snezhnaya, located in Lake Baikal's southern basin $\left(51^{\circ} 42^{\prime} 07^{\prime \prime} \mathrm{N}, 105^{\circ} 00^{\prime} 40^{\prime \prime} \mathrm{E}\right)$. Samples were preserved with Lugol's iodine solution. Forty-eight Lake Baikal sediment samples examined in Stoermer et al. (1995) and Edlund et al. (1995) were also studied. Additional preserved material containing Aulacoseira baicalensis was available from two plankton collections from Baikal's central and northern basin that were collected on 29 and 30 May 1994, respectively. Slides and material used in this investigation were deposited in the General Collection at the Academy of Natural Sciences of Philadephia and in the Center for Great Lakes \& Aquatic Sciences Diatom Herbarium (UM-Stoermer, Dr. E. F. Stoermer, Curator).

For light microscopy, organic material in plankton samples was gently oxidized overnight in cold $30 \% \mathrm{H}_{2} \mathrm{O}_{2}$ (Van der Werff 1955). Six subsequent rinses of the cleaned material with distilled water each followed by $6 \mathrm{~h}$ of settling removed the oxidation byproducts. Cleaned material was air-dried onto coverslips and mounted on microscope slides using Hyrax or Naphrax $\otimes$. Additional aliquots were air-dried onto coverslips. The coverslips were mounted on aluminum stubs with conductive paint, sputtercoated with $20 \mathrm{~nm}$ gold, and examined at $25 \mathrm{kV}$ accelerating voltage in a JEOL JSM-T 100 scanning electron microscope. A Leitz Dialux 20 microscope fitted with full immersion bright field optics of N. A. $\geq 1.32$ was used for light microscopy. Valve dimensions (diameter and mantle height) and areolar and strial densities were measured using both wet mounts and permanently mounted material. Measurements were accomplished using digitized images from the preceding microscope outfitted with a Panasonic Model WV1410 video camera connected to a Macintosh Centris 650 computer with a Data Translation Quick Capture Card frame grabber (Stoermer 1995). The software package NIH Image 1.54 (written by Wayne Rasband at the L:S. National Institutes of Health and available on the Internet by anonymous ftp from zippy.nimh.nih.gov or on floppy disk from XTIS, 5285 Port Royal Road, Springfield, Virginia 22161, part number PB93504868 ) allowed rapid assessment of multiple morphological pa- rameters from a single digitized image. All measurements from digitized images were calibrated against a Bausch \& Lomb \#370 stage micrometer.

Terminology of diatom valve ultrastructure follows proposals by Ross et al. (1979), Round et al. (1990), and Krammer (1991).

\section{RESULTS}

Aulacoseira Thwaites was resurrected by Simonsen (1979) to separate the freshwater forms with marginal spines (linking and separation) and straight or curved rows of areolae on the mantle (e.g. the $M e$ losira gramulata (Ehrenb.) Ralfs, $M$. italica (Ehrenb.) Kütz., $M$. distans (Ehrenb.) Kütz., and $M$. islandica O. Müll. groups) from Melosira sensu lato. In our investigations of sediment and modern phytoplankton collections from Lake Baikal, we have identified two common Aulacoseira taxa. The more coarse form corresponds to the description of $A$. baicalensis (Wislouch 1924, Skabitschewsky 1929, Genkal and Popovskaya 1991b, Likhoshway et al. 1992, 1993) and was abundant in all three basins of the lake in spring 1994 and is well preserved in recent sediments throughout the lake (Edlund et al. 1995, Stoermer et al. 1995). The second Aulacoseira was commonly preserved only as spores in surficial sediments throughout the lake (Stoermer et al. 1995), but both vegetative and spore-producing filaments were abundant in the southern basin plankton collection from Lake Baikal in spring 1994. Contemporaneous plankton collections from the central and northern basin did not contain this taxon, possibly reflecting the extreme latitudinal and interbasin differences during iceout and vernal productivity. Herein we describe the second taxon as $A$. skvortzowii.

\section{Aulacoseira skvortzowii}

M. B. Edlund, E. F. Stoermer \& C. M. Taylor sp. nov.

Species planctonica, frustula vegetativa cylindrica, in facie laterali rectangulari, in facie valia ri circulari, spinis spathulatis in catenas longas conjuncta, cellulae ter-

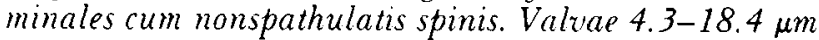
in diametro, limbi 15.4-26.0 $\mu \mathrm{m}$ alti. Areolae in limbo cum orificiis zariabilis externis in striis rectis vel leviter spiralibus pervalvaribus bipunctatae dispositae. Striae 13.3-18.3 in $10 \mu \mathrm{m}$. Areolae in limbo 14.4-20.5 in 10 $\mu \mathrm{m}$. Areolae in limbo et facie valviari velo interno et variabili rotis occlusae. Pseudoseptum perpusillum aut absens. Multae sessilis rimoportulae in limbo dispersae, externae aperturae substitutae areolas in striis. Singularis hypnospora endogena per cellula vegetativa producta. Hypnospora cylindrica cum facie valiari semisphaerica. Epizalia cum altitudine breviore limbi. Valvae 5.2-18.7 um in diametro, limbi 12.9-24.2 $\mu$ m alti. Areolae in limbo cum orificiis externis ovalibus-circularibus in striis rectis iel leviter spiralibus perialvaribus singulatim-punctatis dispositae. Striae 12.0-16.2 in $10 \mu \mathrm{m}$. Areolae in limbo 11.8-16.5 in $10 \mu \mathrm{m}$. Areolae in limbo et facie ralvari rotis et ielo interno occlusae. Pseudoseptum latum sed 
tenue, in cellulam interior expansum. Rimoportulae multae sessilis in limbo dispersae, externae aperturae substitutae areolas in striis.

Holotypus: ANSP General Collection \#36313a.

Isotypus: UM-Stoermer No. 4780, MBE No. 659.

Species planktonic, vegetative frustules cylindrical, rectangular in girdle view, circular in valve view, joined in long filaments by spathulate marginal interlocking spines, end cells with nonspathulate spines. Vegetative valves $4.3-18.4 \mu \mathrm{m}$ in diameter, mantles 15.4-26.0 $\mu \mathrm{m}$ high. Areolae on mantle with variable external openings, arranged in straight to slightly spiralling parallel pervalvar double-punctate striae, striae 13.3-18.3 in $10 \mu \mathrm{m}$. Mantle areolae 14.4-20.5 in $10 \mu \mathrm{m}$. Areolae on mantle and valve face occluded by internal vela and variable rotae; annular pseudoseptum (Ringleiste) very small to nearly absent. Multiple rimoportulae scattered on mantle wall, their external aperatures replacing areolae in striae. A single endogenous resting spore produced per vegetative cell. Resting spore frustules cylindrical with hemispherical valve face. Epivalve with shorter mantle height. Spore valves 5.2-18.7 $\mu \mathrm{m}$ in diameter, mantles 12.9-24.2 $\mu \mathrm{m}$ high. Areolae on mantle with oval to circular external openings, arranged in straight to slightly spiralling parallel pervalvar uniseriate striae, mantle areolae $11.8-16.5$ in $10 \mu \mathrm{m}$, striae $12.0-16.2$ in $10 \mu \mathrm{m}$; areolae on mantle and valve face occluded with rota and internal velum. Annular pseudoseptum (Ringleiste) broad and thin, expanded into cell interior. Multiple rimoportulae scattered on spore mantle wall, their external apertures replacing areolae in the striae.

Holotypes: ANSP General Collection \#36313a.

Isotypes: UM-Stoermer No. 4780, MBE No. 659 .

Type locality: Southern basin of Lake Baikal, Siberia, Russia, $51^{\circ} 42^{\prime} 07^{\prime \prime} \mathrm{N}, 105^{\circ} 00^{\prime} 40^{\prime \prime} \mathrm{E}$.

Etymology: This taxon is named in honor of Benjamin W. Skvortzow, a pioneer diatomist on Lake Baikal and one of the first to realize the uniqueness of the Baikal diatom flora.

Aulacoseira skvortzowii is found in two morphologies: vegetative filaments (Figs. 1, 2) and filaments producing resting spores (Figs. 3-7). Vegetative filaments are much more lightly silicified than resting spore filaments (Figs. 1, 2) and contain two types of valves, linking and separation valves. All vegetative valves have flat valve faces covered with scattered areolae (Figs. 9, 10). The vegetative valve face meets the mantle at right angles. The margin of each face of linking valves is surrounded by spathulate linking spines (Figs. 9, 12). Each interstria on the mantle terminates in a spine, and the narrowed linking spine base is displaced slightly onto the valve face (Figs. $9,12)$. Spines interlock with the next valve in the filament (Fig. 8) and produce a small pseudosulcus visible under light microscopy (Fig. 2B). Filaments end in separation valves. They possess specialized separation spines without any expanded spine terminus or anchor (Figs. 10,11). The vegetative valve mantle is covered with straight to just slightly spiralling longitudinal striae separated by interstriae running nearly parallel to the pervalvar axis (Fig. 10). Striae in both linking and separation valves are made up of complex areolae that usually appear as a double series of mostly alternating areolae (Figs. 10-13). This complexity is difficult to describe because pairs or groups of areolae have been considered to be single areola (Likhoshway et al. 1992). Each areola has a velum on the interior valve surface, and many are occluded externally with rotae (Figs. 12, 13). Some vegetative valves also have stepped mantles (Figs. 8, 10), a size diminution adaptation identified in other members of this genus (Jewson 1992). Valves are subtended by a short collum with scattered small siliceous granules. The collum is not differentiated from the areolate portion of the mantle by any appreciable Ringleiste (annular pseudoseptum) or sulcus (Figs. 8, 11, 13). Multiple sessile rimoportulae are scattered on the interior of the vegetative valve mantle (Fig. 13). Their external openings replace an areolae group along a stria. Vegetative girdle bands were not studied in great detail but were seen to be ligulate open bands with rows of small poroids running parallel to the pervalvar axis (Fig. 13).

Resting spore filaments have four types of valves (Figs. 3-7): vegetative linking, vegetative separation, spore, and attendant valves. Two vegetative valves, with morphology as previously described, surround a single resting spore frustule. The spore frustule itself is separated from the vegetative valves by two attendant valves (Loseva 1981; the rudimentary valve of Syvertsen 1979) with concave valve faces and a shortened mantle height (Figs. 7, 15). Spore valves are more heavily silicified than vegetative valves (Figs. 3, 7). They have a domed valve face with a well-developed cylindrical mantle that gives them a bullet-shaped cross-section (Figs. 3-7, 14). The spore valve face is covered with scattered areolae that are organized in radial rows near the face margin and then continue into straight, uniseriate striae running parallel to the pervalvar axis on the valve mantle (Fig. 14). The spore valve typically has a few small spines at the margin (Fig. 14). External areolar openings on the spore valves are circular to oval; the larger oval areolae appear to be occluded by rotae (Fig. 17). Each areola is also occluded on the internal surface by a velum (Fig. 16). Multiple sessile rimoportulae are scattered on the spore mantle situated along a striae, similar to their positioning in vegetative valves (Fig. 16). A wide collum is present at the distal portion of each spore valve and is covered in small siliceous granules and has a milled edge (Fig. 14). The collum is separated from the areolate portion of the mantle by a welldeveloped solid Ringleiste (annular pseudoseptum) that protrudes into the cell interior (Fig. 16). A small sulcus is evident on the external spore valve surface directly opposite the Ringleiste or annular pseudo- 


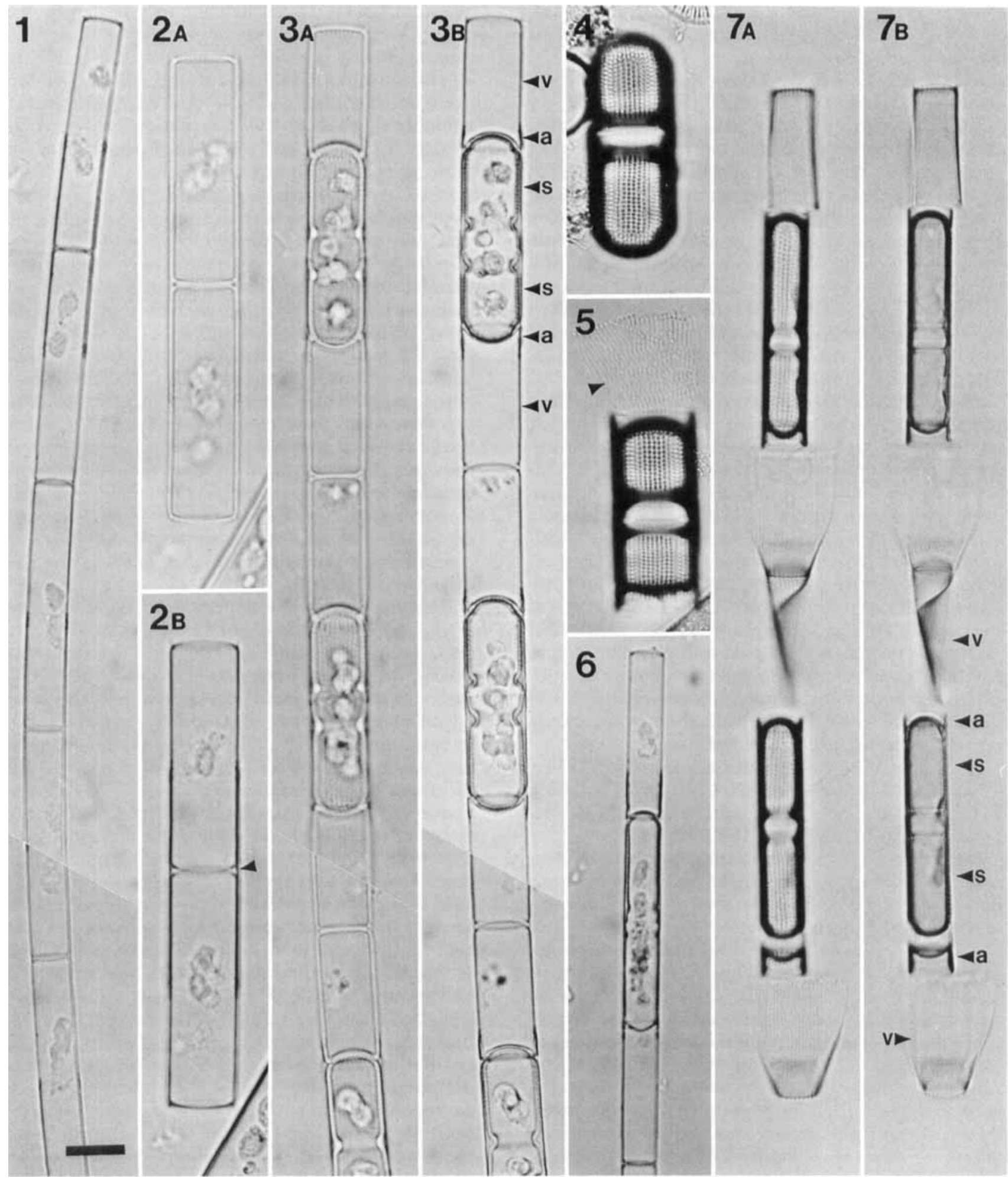

Figs. 1-7. Light micrographs of Aulacoseira skzortzouii. Scale bar $=10 \mu \mathrm{m}$ (in Fig. 1). Figs. 1-3, 6. Preserved material, wet mounts. Fig. 1. Thin vegetative filament. Fic. 2. Thick vegetative filament. A) High focus. B) Midfocus showing pseudosulcus (arrowhead). Fig. 3. Spore-producing filament. A) High focus showing differences in punctate patterns between spores and vegetative cells. B) Midfocus showing arrangement of vegetative (v), attendant (a), and spore (s) valves. Figs. 4, 5. Sedimentary collection of spore frustules, Hyrax mounts. Note remains of vegetative valve in Figure 5 (arrowhead). Fig. 6. Preserved thin spore-producing filament, wet mount. Fig. 7. Hyrax mount of spore-producing flament, iconotype of A. skiortzou'ii. A) High focus showing differences in silicification and punctate patterns between spores and vegetative cells. B) Midfocus showing arrangement of vegetative (v), attendant (a), and spore (s) valves. 

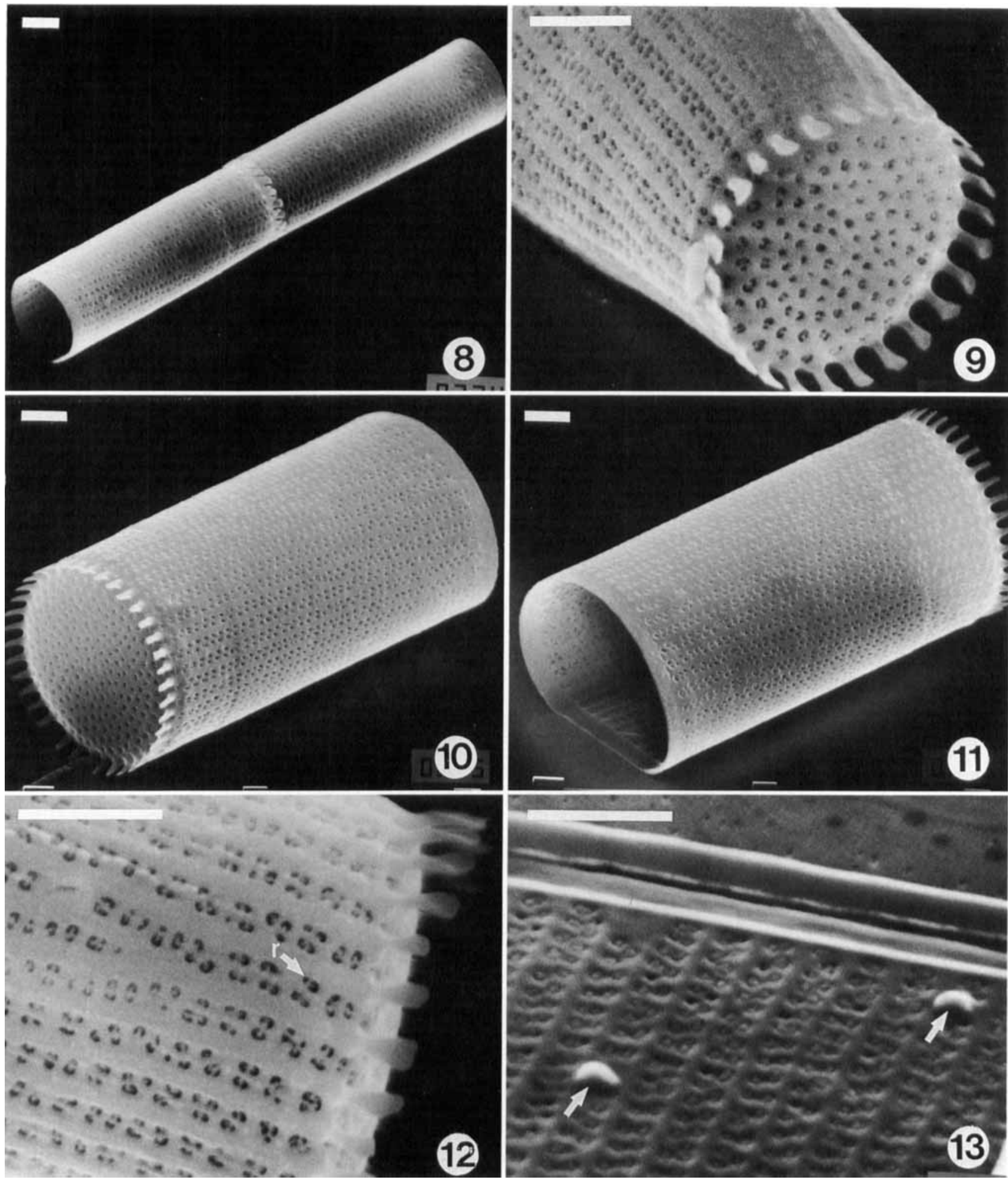

FIGs. 8-13. Scanning electron micrographs of Aulacoseira skvortzowii vegetative valves. Scale bars $=2 \mu \mathrm{m}$. FIG. 8 . Two vegetative linking valves. Note stepped mantle on left valve. Fig. 9. Vegetative linking valve face and margin showing areolar organization and spathulate linking spine structure. Fig. 10. Vegetative separation valve with stepped mantle. Note biseriate striae and separation spines. Fig. 11. Same specimen as in Figure 10. Note short collum and lack of Ringleiste (annular pseudoseptum). Fig. 12. Junction of linking valve face and mantle showing complex areolae structure and spathulate linking spines. Many areolae are occluded with rotae (r). Fic. 13. Internal view of the distal end of a vegetative valve mantle. Two sessile rimoportulae (arrows) are situated along the biseriate striae. Areolae are occluded internally by a velum. At the top of the figure is the valvocopulae (first girdle band) with pervalvar rows of poroids. 
septum (Fig. 14). No girdle bands were found on spore frustules.

The short, concave-faced hypovalves that separate the spore from vegetative valves are nearly as heavily silicified as spore valves (Figs. 7,15 ). These attendant valves often remain tightly attached to the spore valves, confined by the girdle bands from the mother cell (Figs. 5, 7, 15). Their areolar ultrastructure is similar to spore valves (Fig. 15); however, their gross ultrastructure differs. They have a concave face, a much shorter mantle, and no developed Ringleiste or apparent rimoportulae (Fig. 15).

\section{DISCUSSION}

A short note on diatom valve terminology is presented here to clarify several terms that have been used to describe Aulacoseira ultrast ructure and spore production in diatoms. Many Aulacoseira have a siliceous thickening at the juncture of the areolate portion of the mantle and the nonareolate collum. This ring-like thickening projects into the cell interior as a sheet of silica and may be solid or a hollow tube or have a secondary thickening (reinforcing ring) on its innermost surface. It is also sometimes associated with an external groove or sulcus. The German term for this structure is Ringleiste (ringledge), but more recently the term pseudoseptum has been proposed (Haworth 1988, Krammer 1991). Pseudoseptum has also been used to describe internal costae in centric diatoms (Biddulphia biddulphiana, Ross et al. 1979); however, the term pseudoseptum has been more traditionally applied to inwardly projecting sheets of silica (in the valvar plane) from the valve mantle near the terminal ends of pennate diatoms (Ross et al. 1979). We feel that applying this term to both centric and pennate diatoms is incorrect because the pseudoseptum has a specialized role in pennate diatoms as an expanded attachment point for the proximal girdle element or valvocopula (Mastogloia in Stoermer et al. 1964, Gomphoneis in Le Cohu and Coste 1995). For this reason, we feel that the traditional German term, Ringleiste, best describes the ring-like thickening in Aulacoseira. As an appropriate Latinized term has not yet been proposed for this structure, we have included the descriptor annular pseudoseptum in this study. A Ringleiste, or annular pseudoseptum, is prominent in the spores of A. skiortzou'ii (Fig. 16) but absent from the vegetative and attendant valves (Figs. 11, 15).

A second confusing structure is the small concave valve adjacent to the valve face of Aulacoseira ski'ortzouii spores (Figs. 7, 15). These correspond to the hypothecae of the original spore-forming mother valves. Loseva (1981) used the term attendant iali'e for Aulacoseira, which we also prefer, whereas Syvertsen (1979) preferred the term rudimentary ialie when describing a reduced valve found during endogenous spore formation in Thalassiosira. Production of a single spore and this rudimentary valve type is a characteristic of Syvertsen's Type IV endogenous spore formation in centric diatoms (Syvertsen 1979: fig. 4).

While appropriately fixed material was not available for cytological study, Aulacoseira skvortzowii appears to have a distinct type of spore formation. It produces a single resting spore that is contained within the mother cell by girdle bands, suggesting endogenous spore production, yet the spore is separated from the remaining mother cell protoplast by well-developed attendant valves. In $A$. skvortzowii, the attendant valves are not reduced or rudimentary in a similar way as Syvertsen's (1979) Thalassiosira material but are even more heavily silicified than the vegetative mother valves. While it is unfortunate that the cytology of spore formation could not be followed in our material, it is possible to hypothesize the sequence of events producing the $A$. skzortzowii spore (Fig. 18).

We suggest that the cytological sequence of spore formation begins with a single vegetative cell in a filament undergoing a mitotic division to produce the initial spore epivalve and first attendant valve (Fig. 18). The first attendant valve serves as the hypovalve of one of the vegetative mother cells. The cell consisting of the first attendant valve and vegetative valve has minimal protoplast and eventually degenerates. The second mitotic division produces the spore hypovalve and second attendant valve, fully separating the spore from the vegetative mother cell. The frustule consisting of the second attendant valve and vegetative mother valve also contains minimal protoplast and eventually degenerates. The final product from each vegetative mother cell is a series of six valves (Figs. 3B, 7B), which can remain together as a unit within the mother cell girdle bands.

Thus, there may be three types of single endogenous spore production from vegetative cells in diatoms. The first type results in production of a single spore without any rudimentary or attendant valve formation through acytokinetic mitoses (e.g. Urosolenia, Acanthoceras in Schulz 1929, also fig. 8 in Drebes 1974). The second type produces a single resting spore within the mother frustule along with two rudimentary valves as in some Thalassiosira (Syvertsen 1979). The third type, as illustrated by $A u$ lacoseira skiortzowii, results in production of a single resting spore, separated from the mother vegetative cells by heavily silicified attendant valves. Although this third type may more appropriately seem a variation of exogenous spore production, the production of only a single resting spore suggests it is more closely related to endogenous production. Additional endogenous types of spore production include those taxa that produce single endogenous resting spores within the auxospore (e.g. Leptocylindricus danicus; French and Hargraves 1985) and taxa that produce two resting spores per mother cell (e.g. Rhizosolenia setigera; von Stosch 1967).

Spore-forming Aulacoseira are apparently much 

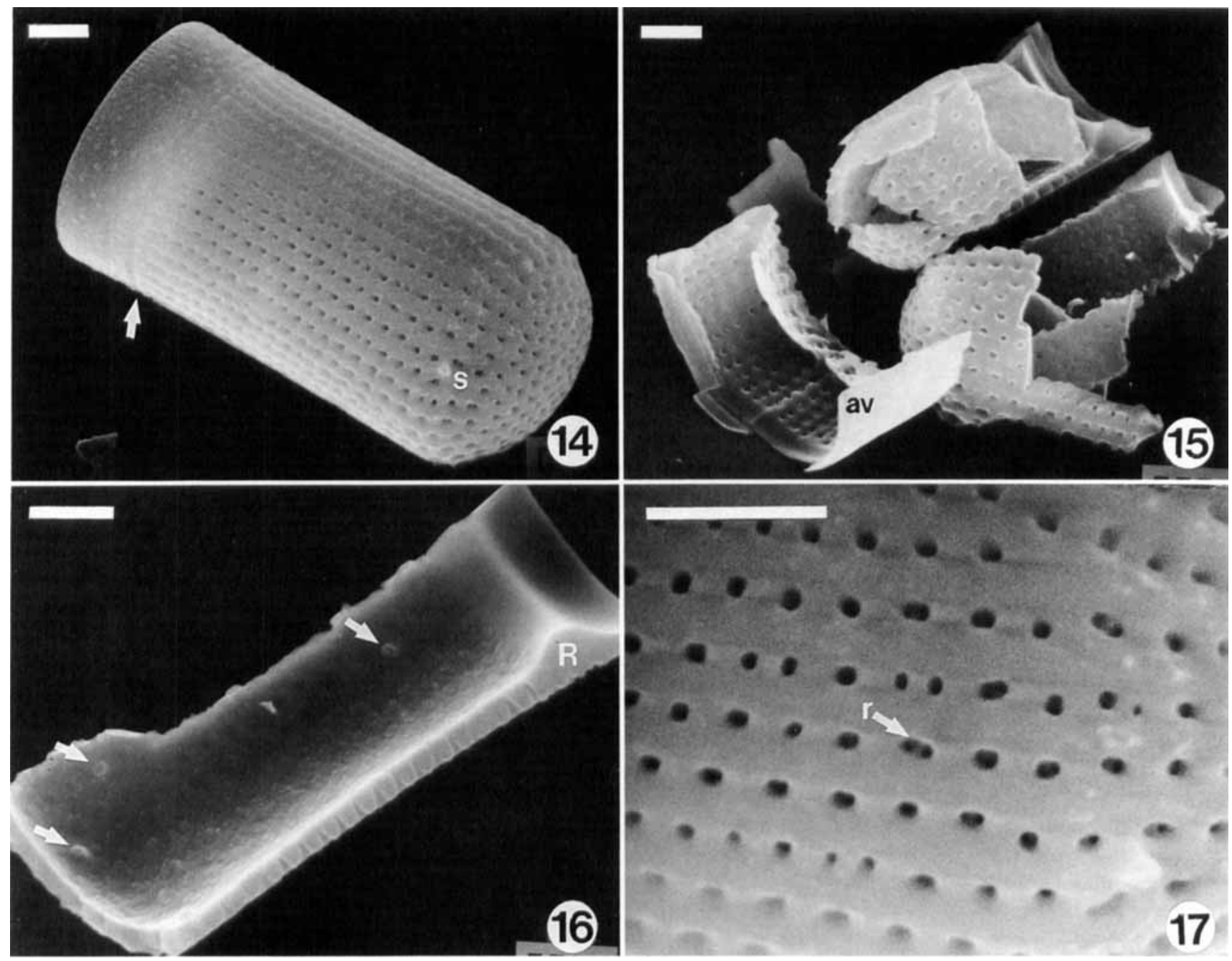

Figs. 14-17. Scanning electron micrographs of Aulacoseira skvortzowii spore and attendant valves. Scale bars $=2 \mu \mathrm{m}$. Fig. 14. External view of spore valve showing wide collum with milled edge, small sulcus (arrow), uniseriate striae, small spine (s), and valve face areolae. FIG. 15. Broken spore and attendant valve. Attendant valve (av) is closer specimen with broken concave valve face, uniseriate striae, and no Ringleiste or annular pseudoseptum development. Fig. 16. Internal view of broken spore valve. Note three scattered rimoportulae on mantle (arrows), a well-developed Ringleiste (R), and areolae occluded internally by vela. Fig. 17. External view of resting spore areolae and striae organization. Areolae have circular to oval external openings often occluded by rotae (r).

more common in fossil deposits than in modern material (Héribaud 1903, Ehrlich 1973, Loseva 1981, Bradbury 1991, Cornet 1991). An extant sporeforming Aulacoseira, probably closely related to specimens illustrated by Müller (1906) as Melosira italica (= M. laevis) or $M$. turgida (Ehrlich 1973), grows ephemerally in prairie potholes in northwest lowa (E. F. Stoermer, unpubl. observ) but differs from $A$. skvortzowii by producing two resting spores per vegetative cell. Melosira charcotii (probably an Aulacoseira under our present concept of the genus) is found in Antarctic maritime meltpools and produces a nearly spherical resting spore frustule (Scherer 1987, S. Spaulding, pers. commun.). A third extant sporeformer, A. skvortzowii, is the subject of this study and has been present in Lake Baikal for at least 200,000 years based on the presence of spores preserved in sediments (Bradbury et al. 1994, Julius 1995).
To resolve the nomenclatural confusion surrounding Aulacoseira skvortzowii and to present an argument that Baikal's populations of this taxon do indeed represent a previously undescribed taxon, we compared our observations with other Lake Baikal and spore-forming Aulacoseira material, published reports, and type descriptions of related taxa (Table 1). We identified morphological differences between A. skvortzowii and closely allied taxa and a notable difference in its perennation strategy that provide ample criteria justifying its description as a separate species (Stuessy 1990, Theriot 1992).

Aulacoseira skvortzowii has most commonly been referred to A. islandica and A. islandica ssp. helvetica, which were both described by Müller (1906) from European (Iceland) material. The location of Müller's original material is unknown, so we have used his type descriptions and illustrations for compari- 


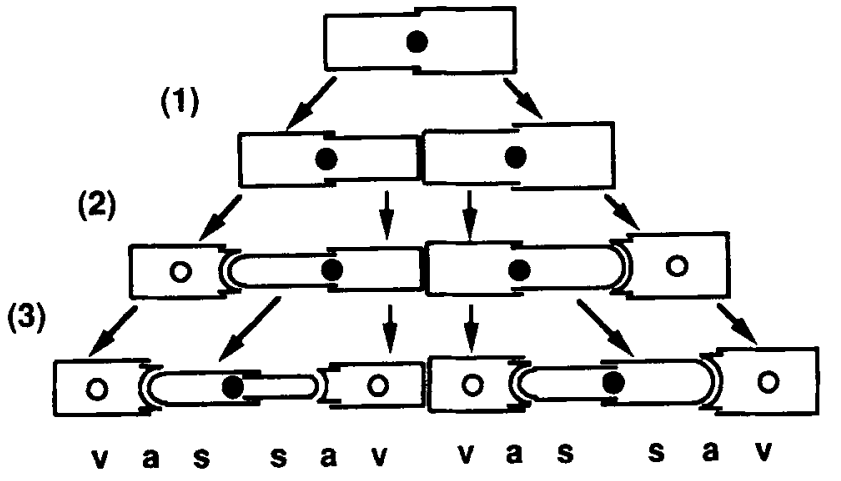

Frg. 18. Hypothesized division scheme of endogenous spore production in two vegetative Aulacoseira skvortzou'ii cells. Division (1) represents a normal vegetative mitosis. Division (2) results in the formation of the spore epivalves and the first attendant valves. Division (3) completes spore formation and produces the second attendant valve. $\mathbf{O}=$ viable cells; $0=$ degenerative protoplasts; letter designations are vegetative valves with doubly punctate striae (v), attendant valves with uniseriate striae (a), and spore valves with uniseriate striae (s)

son. Aulacoseira skvortzou'ii differs from $A$. islandica by the production of spores, narrower minimum diameter, greater mantle height, minimal development of the Ringleiste (annular pseudoseptum), and higher striae and areolae density in the vegetative valves (Table 1). The mantle : diameter ratio is also much greater for $A$. skiortzouiz.

Aulacoseira islandica ssp. helietica has been considered both a subspecies of the nominate (Müller 1906, Kozhova et al. 1982) and as the lower end of a graded series of finer forms of $A$. islandica (Stoermer et al. 1985, Genkal and Popovskaya 1990, 1991a). Aulacoseira skvortzowii differs from A. islandica ssp. helvetica because its vegetative valves tend toward much higher areolae and striae density and have greater mantle height than Müller's (1906) type description (Table 1). Aulacoseira islandica ssp. helretica was also not described as a spore-forming diatom, and although clonal differences in the ability to form resting spores have been reported in other genera, it is a poorly understood phenomenon (Hargraves and French 1983). Later workers have slightly expanded the range of morphological variation encountered in A. islandica ssp. helvetica (Table 1; Huber-Pestalozzi 1942, Cleve-Euler 1951) but not enough to incorporate our observed variation in $A$. ski'ortzou'ii.

One early interpretation of Aulacoseira skz'ortzowii also suggested that it was a sporangial frustule of $A$. baicalensis (Skvortzow 1937). However, Skvortzow's original material was from sediment collections, and recent work has shown that the vegetative frustules of $A$. skiortzouii rarely reach the sediments (Figs. 4, 5), leaving only the spore valves intact (Edlund et al. 1995, Stoermer et al. 1995). Comparison of vegetative valves of $A$. skiortzowii with contemporaneous populations of $A$. baicalensis confirms that they are separate taxa. Aulacoseira baicalensis is a much larger diatom and has more coarse areolae and striae den- sity than A. ski'ortzowii (unpubl. observ., Table 1, also Genkal and Popovskaya 1991b, Likhoshway et al. 1992, 1993). In addition, these two taxa have different autecologies: A baicalensis develops vernally in the pelagic zone of Lake Baikal, whereas $A$. skvortzow ii grows better in nearshore and thermal bar areas (Kozhov 1963, D. H. Jewson, pers. commun.).

To alleviate concerns that Aulacoseira baicalensis may have been described with enough variation to include A. skvortzowii, we also investigated the nomenclatural history of $A$. baicalensis. Wislouch (1924) described Melosira baicalensis (K. Meyer) Wislouch from Lake Baikal material. Wislouch (1924) was unable to find a published description of this taxon but knew from oral communications that K. J. Meyer had used this epithet to describe a Lake Baikal Melosira. Wislouch (1924) thus gave Meyer first authorship and assumed that his material was identical to what Meyer had orally described. Wislouch was unaware of Meyer's (1922) earlier published account where Meyer had described $M$. islandica var. baicalensis K. Meyer. Later authors, including Meyer (Meyer 1925, Skvortzow and Meyer 1928), accepted Wislouch's (1924) description of $M$. baicalensis and that it and $M$. islandica var. baicalensis are synonyms (Wertebnaja 1929, Skvortzow 1937, Proschkina-Lavrenko et al. 1949, Simonsen 1979). The type description of Aulacoseira baicalensis (Wislouch 1924) confirms that it is a much larger diatom and has more coarse areolae and striae density than $A$. skvortzowii (Table 1). Aside from the apparent confusion that led Skvortzow (1937) to include A. skvortzowii spores with his interpretation of $A$. baicalensis, no previous nor later workers have included spores or spore production in their descriptions of $A$. baicalensis (Wislouch 1924, Skvortzow and Meyer 1928, Skabitschewsky 1929, Wertebnaja 1929, HuberPestalozzi 1942, Proschkina-Lavrenko et al. 1949, Kozhov 1963, Genkal and Popovskaya 1991b, Likhoshway et al. 1992).

Other species that may be closely related to $\mathrm{Au}$ lacoseira skvortzouii include $A$. bellicosa (Hérib.) Simonsen and Melosira turgida Ehrlich. Both of these taxa produce resting spores with a valve shape similar to that of A. skvortzowii spores. Aulacoseira bellicosa was described from fossil material by Héribaud (1903) as having cylindrical valves with a hemispherical valve face. However, while mantle and diameter parameters are similar, $A$. sktortzowii spores differ from $A$. bellicosa because they have higher striae and areolar density (Table 1). Ironically, Loseva (1981) also identified spore valves from fossil material as $A$. bellicos $a$ and further suggested that they represented spore valves of $A$. islandica. The morphometric parameters reported by Loseva (1981) for this fossil material differ from the type description of $A$. bellicosa but more closely approximate our material, suggesting a close affinity if not synonomy between the Baikal material and the Kama River Basin taxon. Melosira turgida was described from Israeli fossil de- 


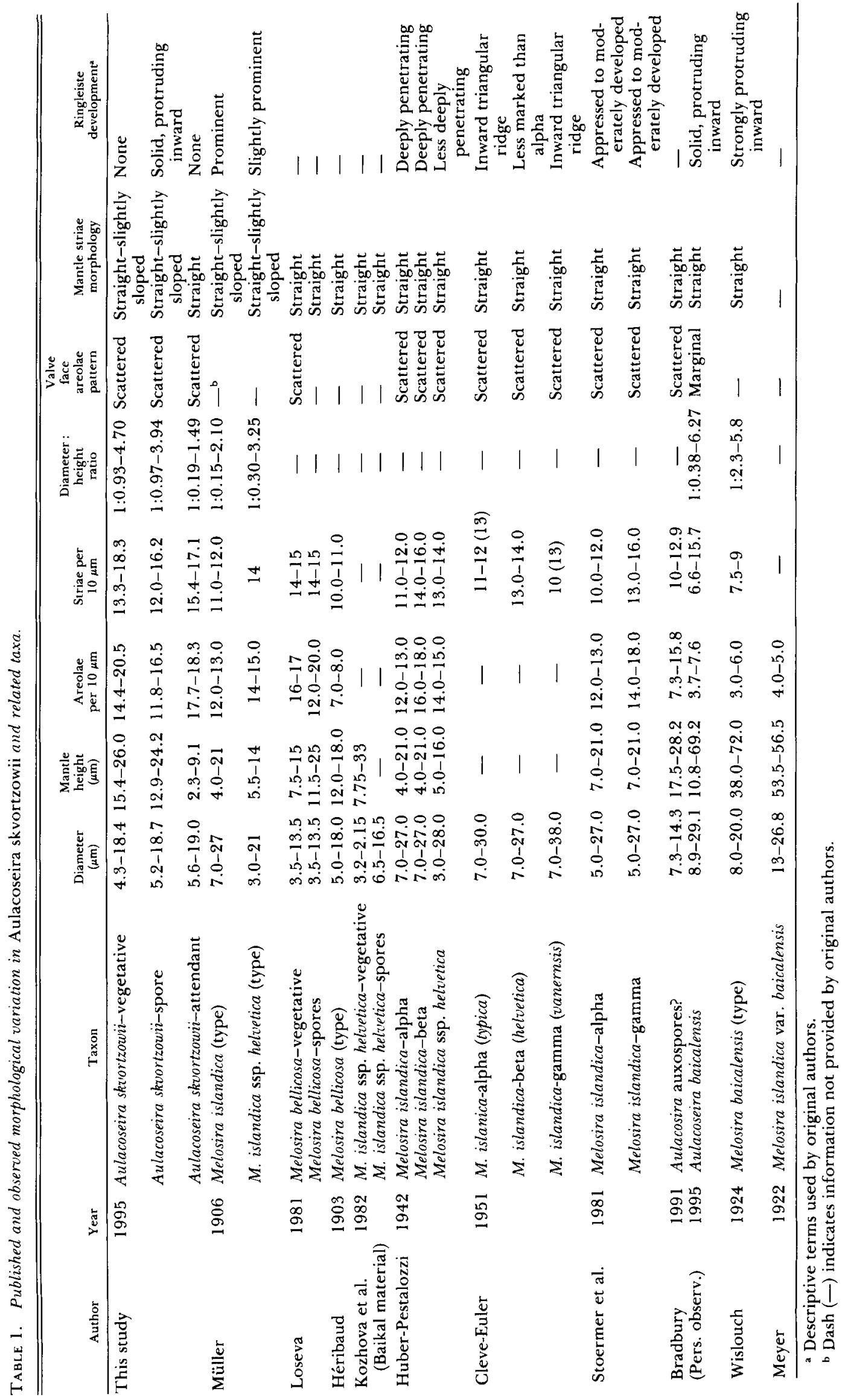


posits (Ehrlich 1973). Melosira turgida is the best described member of a group of similar spore-forming Aulacoseira including $M$. laeiis (Ehr.) Grun. (Van Heurck 1880-1885), M. semilaeris Grun. (Van Heurck 1880-1885), M. italica (Ehr.) Kütz. (Müller 1906), and M. laezis var. fuegiana Frenguelli (Frenguelli 1924). These five taxa differ from $A$. skz'ortzowii in that they each produce two resting spores per vegetative mother cell (Müller 1906) and tend to have slightly curved striae on the spore and vegetative valve mantle.

The production of true resting spores is considered a primitive characteristic of diatoms (Hargraves and French 1983) and has been widely replaced in freshwater phytoplankton by physiological resting cell production (Sicko-Goad et al. 1989). The resting cell perennation strategy apparently provides a more lengthy (decades to centuries) survival potential between reentrainment events into the photic zone. In Lake Baikal, Aulacoseira baicalensis utilizes resting cells as part of its perennation strategy (Bondarenko et al. 1993) whereas $A$. sktortzouii is a true spore-former. It is unknown whether or not $A$. skiortzowii may also utilize resting cells. Baikal's great depths and incomplete mixing (Weiss et al. 1991) suggest that resting cells might provide a better perennation strategy. Unfortunately, little is known of the survivability of Aulacoseira skr'ortzouni resting spores; they may perhaps be a much longerlived resting stage than has been encountered in marine spore-formers (Hargraves and French 1983). Additionally, the prevalence of this taxon in more nearshore and thermal bar collections suggests some evidence of successful annual reentrainment from shallower sediments. Regardless, the resting spore strategy must be well suited to the Lake Baikal environment. Aulacoseira skiortzou'ii has remained morphologically unchanged and present in Lake Baikal for the last 200,000 years (Julius 1995) and probably represents another of the many endemic diatom species characteristic of the world's largest lake.

We thank Mike Wynne and Craig Schneider for helping with the Latin diagnosis, C. W. Reimer for assistance with translations and literature, D. H. Jewson for valuable discussions on the ecology of Baikal Aulacoseira, members of the Baikal Undergraduate Research Group at the University of South Carolina for assisting in collection of material, and Nina Guselnikova, chief scientist aboard the R/V Vereshchagin during the May 1994 cruise. Special thanks are due to Dr. William Murray of the Samuel Freeman Charitable Trust for financial assistance. Contribution 575 from the Center for Great Lakes and Aquatic Sciences was supported in part by NSF Grant EAR-9318683. Additional financial assistance was granted to C.M.T. by the Explorers Club.

Bondarenko, N. A., Guselnikova, N. E., Vorobyeva, S. S. \& Logacheva, N. F. 1993. Species composition of planktonic diatom algae of Lake Baikal and biology of dominant species. In Fifth Workshop on Diatom Algae: Diatom Algae as Indicators of the Changes of Climate and Entironment. Russian Academy of Sciences, Siberian Division, Irkutsk, 16-20 March 1993, pp. 72-5.
Bradbury, J. P. 1991. The late Cenozoic diatom stratigraphy and paleolimnology of Tule Lake, Siskiyou Co., California. J. Paleolimnol. 6:205-55.

Bradbury, J. P., Bezrukova, Ye. V., Chernyaeva, G. P., Colman, S. M., Khursevich, G., King, J. W. \& Likoshway, Ye. E. 1994. A synthesis of post-glacial diatom records from Lake Baikal. J. Paleolimnol. 10:213-52.

Cleve-Euler, A. 1951. Die Diatomeen von Schweden und Finnland. Teil 1. Kungl. Suenska. Vetskapakademiens Handlingar, Fjärde Serien, Band 2, No. 1, pp. 1-163, 56 Tafeln.

Cornet, C. 1991. Le Maar de Nogaret (France): assemblages diatomiques de la fin du Pliocene. In Actes du XI Colloque des Diatomistes de Langue Francaise, 24-27 September 1991, pp. 219-27.

Drebes, G. 1974. Marines Phytoplankton. G. Thieme, Stuttgart, $186 \mathrm{pp}$.

Edlund, M. B. \& Stoermer, E. F. 1993. Resting spores of the freshwater diatoms Acanthoceras and Urosolenia. J. Paleolimnol. 9:55-61

Edlund, M. B., Stoermer, E. F. \& Pilskaln, C. H. 1995. Siliceous microfossil succession in the recent history of two basins in Lake Baikal Siberia. J. Paleolimnol. 14:165-84.

Ehrlich, A. 1973. Quaternary diatoms of the Hula Basin (Northern Israel). Geol. Sur. Israel, Bull. 58:1-39.

Flower, R. J. 1993. A taxonomic re-evaluation of endemic $C y$ clotella taxa in Lake Baikal, Siberia. Nova Hedwigia Beih. 106: 203-20.

French III, F. W. \& Hargraves, P. E. 1985. Spore formation in the life cycles of the diatoms Chaetoceros diadema and Leptocylindrus danicus. J. Phycol. 21:477-83.

Frenguelli, J. 1924. Diatomeas de Tierra del Fuego. Anales de la Sociedad Cientifica Argentina 96:225-63; 97:87-118, 231$66 ; 98: 5-63$.

Genkal, S. I. \& Popovskaya, G. I. 1990. Peculiarities of spore and auxospore morphology and biology of Aulacosira islandica (Bacillariophyta). Acad. Sci. USSR, Biol. Inland Waters, Information Bull, 89:3-6 (in Russian).

1991 a. New data on the frustule morphology of Aulacosira islandica (Bacillariophyta). Diatom Res. 6:255-66.

$1991 \mathrm{~b}$. On the morphology and ecology of Aulacosira baicalensis. Bot. Zh. 76(2):292-3 (in Russian).

Hargraves, P. E. \& French, F. W. 1983. Diatom resting spores: significance and strategies. In Fryxell, G. [Ed.] Survival Strategies of the Algae. Cambridge University Press, New York, pp. 49-68.

Haworth, E. Y. 1988. Distribution of diatom taxa of the old genus Melosira (now mainly Aulacoseira) in Cumbrian waters. In Round, F. E. [Ed.] Algae and the Aquatic Environment. Biopress, Bristol, pp. 138-67.

Héribaud, J. 1903. Les Diatomées Fossiles D'Auvergne, 2nd Mem. Librairie des Sciences Naturelles, Paris.

Huber-Pestalozzi, G. 1942. Das Phytoplankton des Susswassers; Systematik und Biologie. In Thienemann, A. [Ed.] Die Binnengewässer, 2. Teil, 2. Halfte Diatomeen. E. Schweizerbartsche Verlagsbuchhandlung, Stuttgart, pp. 367-549.

Jewson, D. H. 1992. Size reduction, reproductive strategy and the life cycle of a centric diatom. Phil. Trans. R. Soc. Lond. B 336:191-213.

Julius, M. J. 1995. Paleoclimatic implications of Late Quaternary sediments in Lake Baikal, Siberia. M.Sc, thesis, University of Michigan, Ann Arbor, 62 pp.

Kozhov, M. M. 1963. Lake Baikal and Its Life. Dr. W. Junk Publishers, The Hague, $344 \mathrm{pp}$.

Kozhova, O. M., Shastina, N. A. \& Kaplina, G. S. 1982. Size characteristics of Melosira islandica ssp. helvetica O. Müll. from Lake Baikal. Hydrobiol. J. 18:6-10.

Krammer, K. 1991. Morphology and taxonomy of some taxa in the genus Aulacoseira Thwaites (Bacillariophyceae). I. Aulacoseira distans and similar taxa. Nova Heduigia 52:89-112.

Kuwata, A., Hama, T. \& Takahashi, M. 1993. Ecophysiological characterization of two life forms, resting spores and resting cells, of a marine planktonic diatom, Chaetoceros pseudocuriisetus, formed under nutrient depletion. Mar. Ecol. Prog. Ser. 102:245-55. 
Le Cohu, R. \& Coste, M. 1995. Le genre Gomphoneis (Bacillariophyta): un nouveau modéle d'organisation du cingulum. Can. J. Bot. 73:1 12-20.

Likhoshway, Ye. V., Nikiteeva, T., Pomazkina, G. \& Meleshko, Ye. 1993. Fossil diatom algae of Lake Baikal. In Fifth Workshop on Diatom Algae: Diatom Algae as Indicators of the Changes of Climate and Environment. Russian Academy of Sciences, Siberian Division, Irkutsk, 16-20 March 1993, pp. 95-8.

Likhoshway, Ye. V., Yakushin, A. O., Puzyr, A. P. \& Bondarenko, N. A. 1992. Fine structure of the velum and girdle bands in Aulacoseira baicalensis. Diatom Res. 7:87-94.

Loseva, E. 1. 1981. Some common fossil diatoms from the East European Plain (the Kama River Basin) and the Massif Central. In Ross, R. [E.d.] Proceedings of the Sixth Symposium on Recent and Fossil Diatoms. Koeltz, Koenigstein, pp. 75-80.

Meyer, K. I. 1922. Quelques recherches scientifiques sur la flore des algues du lac Baikal. J. Moscow Branch Russian Bot. Soc. 1: 1-27 (in Russian).

1925. Sur l'endémisme de la floré algologique du Lac Baikal. Rer. Algol. 2:241-57.

1930. Einführung in die Algenflora des Baicalsees. Bull. Soc. Nat. Moscou, Sect. Biol. 39:179-396.

Müller, O. 1906. Pleomorphismus, Auxosporen und Dauersporen bei Melosira-Arten. Jahrb. Wiss. Bot. 43(1):49-88, 2 pls.

Popovskaya, G. I. 1991. Phytoplankton of Lake Baikal and its long-term changes (1958-1990). Dissertation Abstract: Academy of Sciences, Siberian Division, Central Siberian Botanical Garden, Novosibirsk, 32 pp. (in Russian).

1993. Planktonic diatom algae of Lake Baikal and their long-term monitoring. In Fifth Workshop on Diatom Algae: Diatom Algae as Indicators of the Changes of Climate and Environment. Russian Academy of Sciences, Siberian Division, Irkutsk, 16-20 March 1993, pp. 114-6.

Proschkina-Lavrenko, A. I., Zuze, A. P., Zabelina, M. M., Kiselev, I. A., Poretzky, V. S. \& Sheshukova, V. S. 1949. Diatomozyi Analiz. Kniga 2 i 3. Opredelitel Diatomovykh Vodorosle. Poriadok Centrales i Mediales. Sostavili A. P. Jousé (p. 14224, Taf. 1-101); I. A. Kiselev (p. 14-209); V. S. Poretzky (p. 14-209), A. I. Proschkina-Lavrenko (p. 210-224) i V. S. Sheshukova. Akad. Nauk SSSR, 238 pp., 101 Taf., MoskvaLeningrad (in Russian).

Ross, R., Cox, E. J., Karayeva, N. I., Mann, D. G., Paddock, T. B. B., Simonsen, R. \& Sims, P. A. 1979. An amended terminology for the siliceous components of the diatom cell. Nova Hedwigia Beih. 64:513-33.

Round, F. E., Crawford, R. M. \& Mann, D. G. 1990. The Diatoms: Biology and Morphology of the Genera. Cambridge University Press, Cambridge, $747 \mathrm{pp}$.

Rushforth, S. R. \& Johansen, J. R. 1986. The inland Chaetoceros (Bacillariophyceae) species of North America. J. Phycol. 22: 441-8.

Scherer, R. P. 1987. Paleoenvironmental studies of nonmarine diatoms in Quaternary antarctic sediments. Antarct. J. NSF 22(5):35-7.

Schulz, P. 1929. Über Zellteilung und Dauersporenbildung der Diatomeengattungen Attheya und Rhizosolenia. Bot. Arch. 24: 505-23.
Sicko-Goad, L., Stoermer, E. F. \& Kociolek, J. P. 1989. Diatom resting cell rejuvenation and formation: time course, species records and distribution. J. Plankton Res. 11:375-89.

Simonsen, R. 1979. The diatom system: ideas on phylogeny. Bacillaria 2:9-71.

Skabitschewsky, A. P. 1929. Uber die Biologie von Melosira baicalensis (K. Meyer) Wisl. Russische Hydrobiologische Zeitschrift 8(4-5):93-114 (in Russian).

Skvortzow, B. W. 1937. Bottom diatoms from Olhon Gate of Baikal Lake, Siberia. Philipp. J. Sci. 62(3):293-377.

Skvortzow, B. W. \& Meyer, C. I. 1928. A contribution to the diatoms of Baikal Lake. Proc. Sungaree Rizer Biol. Stn. 1(5): $1-55$.

Stoermer, E. F. 1995. A simple, but useful application of image analysis. J. Paleolimnol. (in press)

Stoermer, E. F., Edlund, M. B., Pilskaln, C. H. \& Schelske, C. L. 1995. Siliceous microfossil distribution in the surficial sediments of Lake Baikal. J. Paleolimnol. 14:69-82.

Stoermer, E. F., Kreis, R. G. \& Sicko-Goad, L. 1981. A systematic, quantitative, and ecological comparison of Melosira islandica $\mathrm{O}$. Müll. with $M$. granulata (Ehr.) Ralfs from the Laurentian Great Lakes. J. Great Lakes Res. 7:345-56.

Stoermer, E. F., Pankratz, H. S. \& Drum, R. W. 1964. The fine structure of Mastogloia grevillei Wm. Smith. Protoplasma 59: $1-13$.

Stoermer, E. F., Wolin, J. A., Schelske, C. L. \& Conley, D. J. 1985. Variations in Melosira islandica valve morphology in Lake Ontario sediments related to eutrophication and silica depletion. Limnol. Oceanogr. 30:414-8.

Stuessy, T. F. 1990. Plant Taxonomy. Columbia University Press, New York, 514 pp.

Syvertsen, E. E. 1979. Resting spore formation in clonal cultures of Thalassiosira antarctica Comber, $T$. nordenskioeldii Cleve and Detonula confervacea (Cleve) Gran. Nova Hedwigia Beih. 64:4163.

Theriot, E. 1992. Clusters, species concepts, and morphological evolution of diatoms. Syst. Biol. 41:141-57.

Van der Werff, A. 1955. A new method of concentrating and cleaning diatoms and other organisms. Verh. Int. Ver. Theor. Angew. Limnol. 12:276-7.

Van Heurck, H. 1880-1885. Synopsis des Diatomées de Belgique. Edite Par L'auteur, Anvers.

von Stosch, H. A. 1967. Diatomeen. In Ettl, H., Müller, D. G., Neumann, K., von Stosch, H. A. \& Weber, W. [Eds.] Vegetative Fortpflanzung, Parthenogenese und Apogamie bei Algen. Handbuch der Pflanzenphysiologie (Ruhland, W. [Ed.]) 18:657-81. Springer-Verlag, Berlin.

Weiss, R. F., Carmack, E. C. \& Koropalov, V. M. 1991. Deepwater renewal and biological production in Lake Baikal. Nature (Lond.) 349:665-9.

Wertebnaja, P. I. 1929. Über eine relikte Algenflora in den Seeablagerungen Mittelrusslands. Arch. Hydrobiol. 20:124-33.

Wislouch, S. M. 1924. Beiträge zur Diatomeenflora von Asien. II. Neuere Untersuchungen über die Diatomeen des BaikalSees. Ber. Deutsch. Bot. Ges, 42:163-73. 